International Journal of Linguistics, Literature and Translation

ISSN: 2617-0299 (Online); ISSN: 2708-0099 (Print)

DOI: $10.32996 / \mathrm{ijllt}$

Journal Homepage: www.al-kindipublisher.com/index.php/ijltt

IJLLT

\title{
A Morphosyntactic Analysis of Some Asante Weed Names
}

\author{
Abdulai Akuamah 8 (D) \\ Department of Languages, St. Joseph's College of Education, Bechem, Ghana. \\ $\triangle$ Corresponding Author: Abdulai Akuamah, E-mail: akuamha81@gmail.com
}

ARTICLE INFORMATION

Received: April 08, 2021

Accepted: May 14, 2021

Volume: 4

Issue: 5

DOI: $10.32996 /$ ijllt.2021.4.5.21

\section{KEYWORDS}

weed names, morphosyntactic

analysis, Asante, lexical

morphology, morphology, syntax

\section{ABSTRACT}

This paper investigates the morphosyntactic features of some indigenous weed names identified among the Asante people of Ghana. Asante is a dialect of Akan and belongs to the Kwa (Congo-Niger) language family spoken mainly in Southern Ghana. This paper discusses some forty-four (44) weed names in Asante. All the data used were collected from primary sources. The data were collected from twenty (20) native speakers of Asante through unstructured interviews. The study has revealed various morphological processes in the language that include affixation, reduplication, and compounding in terms of morphological structure. The weed names were morphologically structured as single words, di-morphemic, phrases and clauses reduced to weed names. Syntactically, these sentential names can be simple, compound, and complex sentences which can function as declarative and imperative sentences.

\section{Introduction}

Every language in the world make use of names (Anderson 2007). We use names to refer to things we want to talk about in everyday life. The number and types of names that are ascribed to persons, places, animals, rivers, etc., are highly culture specific (Van Langendonck, Velde and Hough, 2016). According to Köhnlein (2015), names are an essential category of linguistics. De Klark (2002) reinforces this idea by stating that conferring names on persons is mainly a linguistics act closely linked to hopes, values, thanksgiving, fears, and events in the life of the name-giver. Obeng (1998) also indicates that Akan names may reflect the geographical environment, religion, beliefs, fears, and the people's philosophy of life. Generally, there is a closed resemblance between a name and the name-bearer. In this way, the name reacts to the culminating experiences of the name-giver. According to Agyekum (2016), Akan names depict the characteristics of the name-bearer.

Mphande (2006) observes that names present interesting features that reveal semantic and morphological processes involved in their constructions. He further stressed that in many African cultures, name labels the individual that it denotes, the language from which it is drawn, and the society that ascribes it. He goes on to explain that a name may reveal the linguistic features and phonological processes found in the language, the status of referent in the society, and the collective history and the life experiences of the people surrounding the individual. This assertion is supported by Kongo and Mends (2016), who observe that construction of names to a large extent depends on the semantics importance the name-giver wants to put across "followed by the morphological processes which largely depend on the deployment of a network of affixes that are harmonized by relevant phonological rules." (p. 610).

Köhnlein (2015) investigated the morphological structure of Dutch names. After the analysis he concluded that the complex place names derived through suffixation or compounding demonstrated a regular phonological pattern. He found the place names to be morphologically complex as against theoretical literature claim that place names are morphologically simple. Furthermore, a study by Kongo and Mends (2016) on contemporary Ewe names showed that the names were morphologically and syntactically determined. The morphological structure demonstrated that the various morphological processes included affixation, reduplication and compounding. Syntactically, the names were discovered to be declaratives, imperatives, clefts, clauses, and

\section{K C AL-KINDI CENTER \\ $R$ DFOR RESEARCH AND DEVELOPMENT}

Your gateway to world-class research

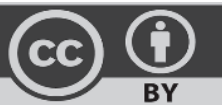

Published by Al-Kindi Center for Research and Development, London, United Kingdom. Copyright (c) the author(s). This open access article is distributed under a Creative Commons Attribution (CC-BY) 4.0 license 
phrases names. Onukawa (1995) also discussed Igbo personal names and concluded that lgbo names are derived from clauses. The study further revealed morphological process where the subject, the verb, and the complement are fused, resulting in the formation of a noun. A process he referred to the process as decontextualization.

Owu-Ewie (2014), on his part, conducted a study on Fante habitation names (econym). His findings revealed that some Fante habitation names are morphologically structured as single stems, compounds, inflections (affixation), and reduplication. The study further demonstrated that Fante habitation names at sentential level could function as statements, interrogatives or imperatives. Structurally, the sentential place names were classified as simple, compound, or complex sentence. A study conducted by Adomako (2017) on personal female names demonstrates, the male names are usually suffixed with the suffixes; $\{-\mathrm{a}\}$ or $\{$-aa\} or $\{$-wa $\}$ to form female names in Akan.

Furthermore, Koopman and Turner (2019) revealed that Zulu bird names usually have prefix or suffix, indicating whether the name is singular or plural. They indicate that a generic folk name can give rise to a number of semantically related names which are morphologically distinct.

Given the linguistics underlying the formation of personal names, habitation names and bird names in Akan, Igbo, Ewe, Dutch, and Zulu we can conclude that names in general are heavily endowed with morphological, syntactic and semantic features. This gives credence to Batoma (2006) claim that names are given in particular languages whose morphology, syntax and semantics inform their meaning to a great extent. Nonetheless, Croft (2001) argues that the semantics of a linguistic expression largely determines its morphosyntactic construction. To this end, the semantic status of a name is mirrored by certain syntactic called 'symbolic' (Van Langendonck 2007). This implies that in order to understand how a group of people construct names in their language, it is imperative to determine the morphosyntactic compositions of the names. It is intriguing how names are constructed in different languages, especially in African cultures. The studies on the various kinds of proper names in Akan and other languages provide a solid foundation for all languages. Therefore, it is important to establish what holds true for some weed names in Asante dialect of Akan and this is the central impetus of this study.

Asante is part of the Akan ethnic group, a branch of the Kwa (Congo-Niger) language family spoken mainly in Southern Ghana and parts of the Ivory Coast. They are found in the Asante region of Ghana and speak Twi as their dialect. The Akans constitute the largest ethnic group in Ghana. The group consists of the Asante, Fante, Bono, Akuapem, Wassa, Assin, Twifo, and Denkyira. The Nzema, Sehwi, Anyi, Baule, Ahanta, and Guans speak Akan in addition to their language (Dolphyne 2006). It is estimated that $49.1 \%$ of Ghana's population are native speakers of Akan while 44\% speak the language as a second language (Agyekum, 2006). Three of these dialects of Akan namely, Asante, Fante and Akuapem have attained literary status (Titov, 2019).

\section{Literature Review}

Lexical Morphology as proposed by Katamba (1993) is a linguistic model developed out of generative grammar (GG) model championed by Chomsky (1957). Lexical Morphology (LM) is a method of morphological analysis where words are broken down into functional, meaningful lexical units whose grammatical meanings can be determined or understood (Kongo and Mends, 2016). According to Mwangi (2015), the main objective of GG is to recognize the nature of linguistic knowledge that language users exhibit.

In the view of grammarians, the human mind is capable of creating an indefinite number of words. LM aims to analyse such forms and designs a systematic set of rules that apply to those word forms. The morphological processes involved in creating new words into a language involve inflection, derivation, compounding, and reduplication. Mwangi (2015) further argues that this theory makes it possible to analyse word forms at different levels namely; phonological, morphological or syntactical.

\subsection{Empirical Studies on Plant Names}

The names given to plants have underlying semantico-syntactic to communicate meaning (Leyew 2011). Therefore, names given to the plants among the Asantes mirror the society of the name-givers. In the context of this paper, a weed is defined as any plant growing where it is not wanted or a plant or vegetation that interferes with the objectives of farming (Popay 2018). He explains further that, a plant may be useful in a garden, or on a farm or plantation but if the same plant is growing where it reduces the value of agricultural produce or spoils aesthetic or environmental values, then it is considered a weed. However, some plants are always weeds regardless of where they grow. This means that any plant is a potential weed being it a herb, a shrub, or a tree.

Pakia's (2016) study on Digo plant names and it was revealed that plant naming among the Digo people of Kenya is endowed with linguistics characteristics. The plant names were found to range from simple words to complex phrases. Variation between the names was attributed to their noticeable semantic features. The simple words are nouns consisting of a prefix and a noun. The primary prefixes $\{\mathrm{mu}-\}$ and $\{\mathrm{m}-/ \mathrm{mi}-\}$ accounted for $80 \%$ of the data used for the study. In addition, there a secondary prefixes $\{$ chi\} and $\{\mathrm{dzi}-\}$ that replaced the primary affixes to denote diminutive. Some of the prefixes also denote female gender but not the case for the male plants. The plants names were also structured as genitive phrases and object phrases. The genitive phrases 
comprise compound words consisting of two independent nouns: chishikio paka 'cat ear'. An example of the object phrases is manwa madzi 'water drinker.'

Green (2009) also examined the linguistic properties of plant names in Ikpána (Logba). The plant names were seen to consist of morphemes which meanings are decipherable. The names of some of the plants were formed via compounding as in 'Jga-(כ)y' and reduplication, eg ofuofuo. Again, the morphemes $\{0 s a\}$ and $\{$ dze $\}$ are attached to the generic name of a plant to indicate whether a plant is male or female. For instance, the male papaya is called Bafunuba osa. Meanwhile, the plants with single stem names cannot be broken into meaningful units. Names in this category were classified as opaque names because they do not have meanings except what they refer to.

The findings from how plants names are formed in Digo and Logba languages support the view that grammar of the morphosyntactic peculiarities of these names are language-specific (Haspelmath (2010). Thus, the morphosyntactic features may vary from one language to the other based on the grammar of the language. This view plus Caesar's (2019) suggestion that names of any type may have morphosyntactic properties; morphemes, phrases, clauses or sentences that function as declarative, imperative, subjection and interrogative structures makes it imperative to subject the weed names in Asante to determine the impact morphology has on the syntactic structure of the Akan language in terms of naming practices.

Many studies have been carried out on Akan names. Majority of them have concentrated on the personal study names. For instance, Agyekum (2006) did a sociolinguistic study on Akan personal names, Ansu-Kyeremeh (2000) worked on the communication nature of Bono personal names, while Obeng (1998) has also worked on Death Preventive names. Studies like Owu-Ewie (2014) also discussed the habitation names in Fante while Adomako (2017) looked at Akan personal female names in the areas of morphosyntax and morphophonemic. However, Akan (Asante) weed names have not been examined. To this end, the current study aimed at filling in the lacuna in the literature on names in Akan by looking at how weed names are structured in terms of morphology and syntax.

\subsection{Purpose of the Study}

The purpose of this study is to investigate the morphosyntactic components of Asante weed names. The paper identifies and categorizes the form and structure of these weed names in Asante. Functions of the structures identified are also discussed.

\subsection{Research Questions}
i. What are the forms of Asante weed names?
ii. Which categories of sentence types can be identified in weed names of Asante?
iii. What are the syntactic functions of the clausal Asante weed names?

\section{Methodology}

The data for the study was collected from 20 communities in five districts/municipalities in Ghana namely; Kwabre East, Sekyere Central, Amansie West, Amansie Central, and Bekwai Municipalities in the Ashanti Region of Ghana. There was no special reason for selecting these communities rather than the researcher's frequent contacts with the indigenes from these areas. Data collection started from March 2018 to March 2019. Some forty-four (44) common local weeds found on the streets, backyards and backyard farms were purposefully selected. In each of the communities, two informants were purposively selected, making the total participants twenty (20) in all. They were selected because of their in-depth knowledge of the language and their regular encounter with these weeds. They were predominantly farmers and traditional healers. They used their institutional memory-intuition in providing the most reliable and etymological meanings of the names of the weeds in the data. The information acquired after my interactions with them served as the basis for the classification of the names into the various grammatical categories. The information obtained from them was useful as it enabled me as a native speaker of the language, to identify the morphological compositions of the words by separating the affixes from the roots. Pictures of the plants were taken and with the aid of a colleague at the Agriculture Department, the common names and the botanical names were provided in English (see appendix 1). The data were descriptively analyzed.

\section{Findings and Discussions \\ 4.1 Morphological Analysis of Asante Weed Names}

This section examines the morphological structures of Asante weed names. The morphological analysis concerns the word. The analysis is done from the view point of Lexical Morphological which concerns breaking down of words into meaningful lexical units whose grammatical units are decipherable. (Kongo and Mends, 2016 p. 612). The study showed that the morphological forms of the Asante weed names were made up of mono-morphemic, di-morphemic and poly-morphemic as in Dangme, Ewe and other languages. The mono-morphemic weed names in Asante are root words that cannot be further broken down into meaningful lexical unit without destroying the words. The analysis of some of the mono-morphemic indicated that they could be arbitrary. 
The di-morphemic structure names are the types of names that can be broken down into two meaningful morphemes. They are compounding, affixation or reduplication. The morphemic components were reduplication compounding, noun phrases and sentences.

4.1.1 Mono-morphemic Weed Names

The weed names analysed revealed that the structures of Asante weed names are mono-morphemic in nature. They are made up of free morphemes; they contain roots capable of standing independently as words. This means that these names cannot be further broken down into smaller units without destroying the word. The meanings of the names that fall under this category are covert. Their meanings may not be deciphered in Asante. The weed names in Asante and their botanical names a presented in (1a-I).

(1)
a. Nyanya
b. Awobs
c. Nyanyamforowa
d. Nunum
e. Nsensan
f. Mfofo
g. Afama
h. Kagya
i. Apวsวmp
j. Funtum
k. Ntropo
I. Akyeapon
'Momordica charantia'
'Phyllanthus muellerianus'
'Mallotus oppositifolius'
'Ocimum gratissimum'
'Eleusinen indica'
'Melanthera scandens'
'Justicia flava'
'Griffonia simplicifolia'
'Pupalia lappacea'
'Funtumia elastic'
'Tropical soda apple'
'Lamb's quarters'

It can be observed from examples (1a-l) that the meanings of the names cannot be deciphered. The meanings of the monomorphemic Asante weed names like Akan family names are not palpable. Thus, they are generally monosemic, which is to say they only carry one meaning: the weed they refer to. As indicated, these words mostly do not have explicit meanings in isolation. However, they became meaningful when they are metaphorically used in proverbs. For instance, kagya is used metaphorically to represent a symbiotic relationship. Nyanyamforowa is used to express belittle, unfairness or disparities in the human society. Fumtum in context can also represent consequences or repercussions, and misfortune. Also, mfofo expresses taking things for granted. Nunum implies weak or vulnerable. The example (1l) is a personal name. This weed was named after a former military leader in Ghana whose era the weed invaded the country.

\subsubsection{The Di-morphemic Weed Names}

The di-morphemic structure of Asante weed names is the types of names whereby the names can be broken down into two meaningful morphemes. The two morphemes can be put together as one word through compounding, affixation as shown in (2 4).

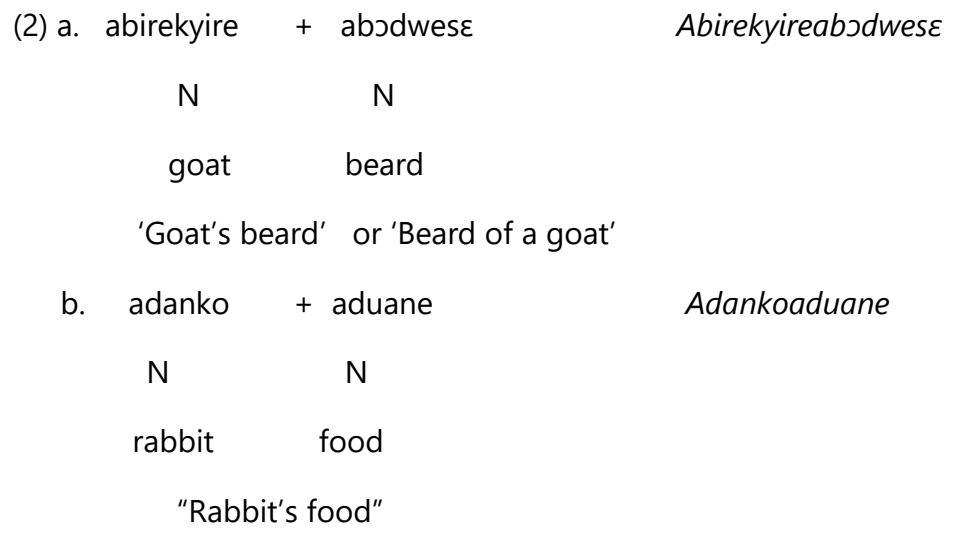


c. ananse

$+\quad$ dəkono

N

spider kenkey

'Food of the spider'

d. ananse

+ akekaduro

N N Spider ginger

'Spider's ginger'

e. akonfem $+$ atiko

N guinea fowl

$$
\text { N }
$$
occiput

'Guinea fowl's comb'

f. adanko + meleke

$\begin{array}{cc}\mathrm{N} & \mathrm{N} \\ \text { rabbit } & \text { milk }\end{array}$

'Rabbit's milk'

g. akokı + mmesa

$\mathrm{N} \quad \mathrm{N}$

Chicken braided hair

'Chicken's braided hair'

h. dua + gyeene Duagyeene

$\mathrm{N} \quad \mathrm{N}$

tree onion

'Onion tree'

i. dua + mako

$\mathrm{N} \quad \mathrm{N}$

dua pepper

'Pepper tree'

j. asawa +

dua

N

N

tree

'cotton's tree'

k. borofere + nini

$\mathrm{N} \quad \mathrm{N}$

papaya male

'male papaya'
Anansedjkono

Ananseakekaduro

Akวnfematik

Adankomeleke

Akoksmmesa

Duamako

Asawadua

Borofenini 


$\begin{array}{lll}\text { I. nunum } & \text { nini } & \text { Nunumnini } \\ \mathrm{N} & \mathrm{N} \\ \text { hoslundia } & \text { male } \\ \text { 'male hoslundia' } & \end{array}$

The data demonstrated that weed names in Asante could be noun-noun compounds. The illustration in (2a - I) is a combination of two nouns to form a single word. Thus, in these examples, animate nouns and inanimate nouns are joined respectively to form the weed names. For instance, animate nouns abirekyire 'goat' adanko 'rabbit', ako 'parrot', ananse 'spider', nantwi 'cattle', akJnfEm 'guinea fowl' and akokJ 'chicken' are animal nouns that function as the head of the compounds in respective words in (2a-e), while the inanimate nouns in these nouns (abjdwese 'beard' aduane. 'food', dokono 'kenkey', akekaduro 'ginger', asaawa 'cotton', atiko 'occiput' and meleke 'milk' 'mmesa'), modify the heads of the compound nouns. Meleke is a borrowed word from English meaning 'milk'. Unlike (2a-e), the names in ( $2 \mathrm{f}-\mathrm{l})$ are composed of two nouns which are both inanimate. The examples in $(2 \mathrm{k}, \mathrm{l})$ are distinguished by the nominal adjective nini 'male' used in Akan to mark gender. In this case, they are attached to the generic name of the plants to determine their sexes.

$\begin{array}{ccc}\text { (3) a. gyina } & \text { Antwi } & \text { Gyinantwi } \\ \text { stop } & \text { Personal Name } & \\ \text { 'Stop Antwi.' } & & \\ \text { b. } \quad \text { toa }+ & \text { ntini } & \text { Toantini } \\ \text { V } & \mathrm{N} & \\ \text { Join } & \text { vein } & \\ \text { 'Join veins.' } & \end{array}$

Some of the di-morphemic nouns were composed of verb-noun compounds. That is, two free morphemes (a verb and a noun) were merged to form weed names as illustrated in $(3 a, b)$. As indicated above, the Asante name for the 'Bidens pilosa', Gyinatwi is a combination of the verbs gyina 'stop' and Antwi 'Personal name'. Again, Toa 'join' and ntini 'veins' are put together to form a new noun, 'Sweet gum.'

$\begin{array}{ll}\text { (4) a. a }+ \text { dwera }(V) & \text { Adwera } \\ \text { AX purify } & \\ \text { 'purifying' } & \text { Jnwono } \\ \text { b. } \supset+\text { nwono } \\ \text { AX ADJ } \\ \text { 'bitter' }\end{array}$

The fourth group in this category is affixation which consists of two morphemes. The morphemic structures of these names have prefixes attached to the roots. They are composed of free morphemes and bound morphemes. The examples (4a, b) are another form of di-morphemic formation of the weed names in Asante. For instance, adwera is weed name derived from the verb dwera which means to "purify". The prefix $\{a-\}$ is attached to the root without altering the root (i.e. prefix + verb). This form of derivation in Asante is "verb to noun". There is also adjective to noun derivation process as seen in example (4b). The root nwono 'bitter' to which the prefix $\{0-\}$ is attached to create the new name is an adjective.

\subsubsection{The Poly-morphemic Weed Names}

The poly-morphemic weed names in Asante are made up of compounding, reduplication, phrases, clauses and sentences. The clause and sentences function as structures. The morphemic forms of the phrasal and sentential names in Asante are made up of free morphemes and bound morphemes. All the declarative weed names are in the affirmative forms as shown in (7a-c). 


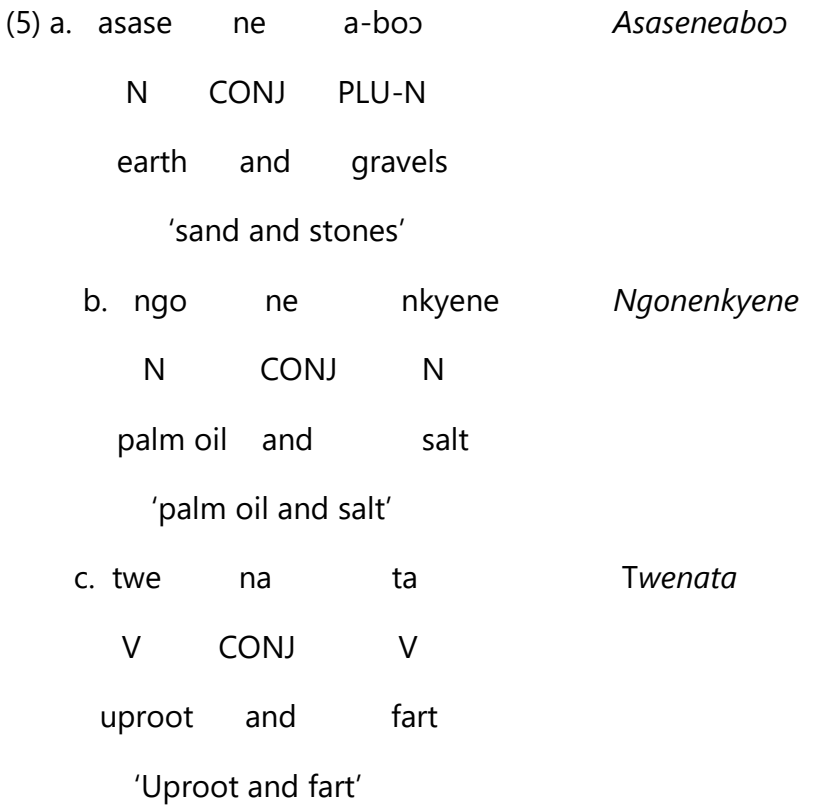

Morphologically, some of the weed names in Asante have compound structure made up of a noun, a conjunction and a noun, and a verb-conjunction-verb. The conjunction puts the two nouns together to denote the name of the plant. The examples (5a-b) above, indicated that the weed names in this category are made up of noun-conjunction-noun are all free morphemes. For instance, asase 'earth', ne 'and', and abos 'gravels' are merged to represent the weed name asaseneabos. The prenominal plural morpheme $\{a-\}$ is attached to the root. Similarly, three free morphemes are merged to engender a new name as in ngo 'palm oil', $n e$ 'and' and nkyene 'salt' see example (5b). While the free morphemes twe 'uproot', na 'and', and ta 'fart' are reduce to form a name for the weed 'cida.'

\section{(6) a. ananse turom ahoma Ananseturomahoma}

$\begin{array}{ccc}\mathrm{N} & \mathrm{N} & \mathrm{N} \\ \text { spider } & \text { anus } & \text { tread }\end{array}$

'A tread in spider's anus'

The morphemic composition of (6a) is noun-noun-noun compound. Thus, the three free morphemes (all nouns) are joined to create a name for the weed 'centrosema' in Asante.

Owu-Ewie (2014) defines reduplication as the process of forming a new word either by doubling entire free morphemes or part of it. Akan made use of both partial and total reduplication of the root. Three weeds were identified in this category. Both roots and prefixes were completely reduplicated. See the table below:

a. n-kasce

n-kasce

N

$\mathrm{N}$

PLU-thorn

PLU-thorn

'thistles'

b. n-kwadaa

PLU-Child PLU-child plantain

'Childrens' Plantain

c. n-kwadaa n-kwadaa borJdec nini

Nkwadaankwadaaborzdenini

NkwadaankwadaaborJdee

Nkascenkasce

PLU-Child PLU- child plantain male

'Male childrens' plantain' 
It can be observed from the data that some of the names are formed through compound reduplication. Obviously, these names are made up of inflectional affixes followed by the noun which is reduplicated in its entirety as demonstrated in (7a). Also, in (7bc) it can be seen that additional noun(s) can be added to the reduplicated root to create new words. Therefore, the weed name consists of an affix-noun-reduplicant-noun compound as indicated in (7a). It can further be observed that the reduplicated noun is in plural form because in Akan only plural nouns may be reduplicated (see Dolyphne 1988). So the morphemic component is a nominal plural prefix $\{\mathrm{n}-\}$ attached to a root kwadaa 'child'. Both morphemes are totally reduplicated and joined to another noun borJdes 'plantain' to create a new word, nkwadaankwadaaborodec.

(8) a. Kaka we adwe Kakatweadwe

$\mathrm{N} \quad \mathrm{V} \quad \mathrm{N}$

Toothache chews palm kernel

'Toothache chews palm kernel.'

b. Pepe a-di a-wuo Pepeadiawuo

$N \quad$ PERF-V PERF-V

Northern eaten die

'A northerner ate and died.'

c. Nyame n-wu na m(e) awu. Nyamenwunamawu

$\begin{array}{llll}N & \text { NEG-V CONJ PRO } & \text { V } \\ \text { God won't-die and I die }\end{array}$

'God won't die so I will not die'

The declaration sentence in (8a) consists of free morphemes. Meanwhile, the sentential names in (8b, c) are composed of both free morphemes and bound morphemes. For instance, in (8b) the bound morpheme $\{a-\}$ which is the perfect marker in Akan is attached to the roots $d i$ and $w u$ to mark the tense. (8c) comprises of free morphemes and has bound morphemes, $\{\mathrm{n}-\}$ and $\{\mathrm{a}-\}$. The progressive negative prefix $\{\mathrm{n}-\}$ attached to the root $w u$ to express negation while the perfect is marked by prefix $\{\mathrm{a}-\}$ in ' $\mathrm{God}$ is not dying so I will not die' Nyamenwunamewu. Again, there is a phonological process where [I] in [mI] "I" is truncated when it precedes low central vowel [a] in Asante Twi.

(9) a. Aberewa kata wo twe Aberewakatawotwe

$\begin{array}{crrr}\mathrm{N} & \mathrm{V} & \text { PRO } & \mathrm{N} \\ \text { Old lady } & \text { cover your vagina } \\ \text { 'Old lady cover you vagina.' }\end{array}$

b. Kra wo ni Krawoni

$\mathrm{N}$ PRO N

bid you mother

'Bid farewell to your mother.'

$\begin{array}{cl}\text { c. Gu a-kuro } & \text { Guakuro } \\ \mathrm{V} & \text { PLU-N } \\ \text { collapse } & \text { towns } \\ & \text { 'deserted towns.' }\end{array}$




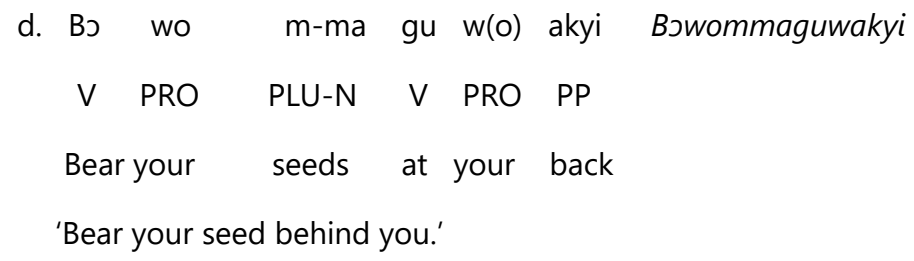

The morphemic components of the sentential imperative weed names in $(9 a, b)$ are made of free morphemes from different word class. However, in $(9 c, d)$, the names are made up of both free morphemes and bound morphemes. The verb root kuro "town" in (9d) and the first root ba (seed) in (9e) to which plural markers $\{a-\}$ and $\{n-\}$ respectively attached are nouns. \{a-\} in (9c) and (9d) are bound morphemes. The bound morphemes; $\{a-\}$ and $\{m-\}$, inflect for the plural forms of akuro and mma. The plural marker $\{\mathrm{m}-\}$ when precedes $/ \mathrm{b} /$ in Asante assimilates to become [m].

\subsection{Syntactic analysis of Akan weed names}

As indicated in the literature, some proper names (place names and personal names) in Akan are made up of phrases and clauses since they have definite word-class elements. They consist of pronouns, nouns, verbs, adjective, postposition and conjunction. Syntactic level means that many of the weed names indicate they are phrases, clauses, and sentences. Let us look at the examples below.

4.2.1. Phrasal weed names

\begin{tabular}{|c|c|c|}
\hline (10) a. abirekyire & + abjdwese & Abirekyireabodwese \\
\hline NP & NP & \\
\hline goat & beard & \\
\hline "Goat's & beard" & \\
\hline b. adanko & + aduane & Adankoaduane \\
\hline NP & NP & \\
\hline rabbit & food & \\
\hline 'rabbit's & food' & \\
\hline c. ako & + bəwerع & Akobowere \\
\hline NP & NP & \\
\hline parrot & nails & \\
\hline 'Parrot's & claw' $^{\prime}$ & \\
\hline d. ananse & + dJkono & Anansedskono \\
\hline NP & NP & \\
\hline Spid & ar's kenkey & \\
\hline e. ananse + & akekaduro & Ananseakekaduro \\
\hline NP & NP & \\
\hline & Spider's ginger & \\
\hline f. akoks + & mmesa & AkokJmmesa \\
\hline NP & NP & \\
\hline Chicken & braided hair & \\
\hline
\end{tabular}

'Chicken's braided hair' 
g. akənfem + atikว
NP NP
guinea fowl occiput
'Guinea fowl's comb'

h. asawa

+ dua

NP NP

cotton

tree

'Cotton's tree'

i. dua

+ gyeene

NP

tree

$$
\text { NP }
$$

onion

'Onion tree'

$\begin{aligned} \text { j. } & \text { dua } \\ \text { NP } & \text { mako } \\ \text { tree } & \text { pepper }\end{aligned}$

'Pepper tree'
Akonfematik

Asawadua

Duagyeene

Duamako

k. borofere + nini Borofenini

$\begin{array}{ll}\mathrm{NP} & \mathrm{NP} \\ \text { papaya } & \text { male }\end{array}$

'Male papaya'

I. nunum + nini

NP NP

hoslundia male

'Male hoslundia'

As we observed from the data $(10 \mathrm{a}-\mathrm{I})$ Asante weed names are composed of noun phrases. Examples in (10a-g) are made up of possessive phrases. Syntactically, these categories of names are structures such that the possessors precede the possessed, as in the case of all noun possessive construction (see Obeng 1998). As exemplified in (10a-g) the first noun is the possessor while the second noun is possessed. In (10h), the noun asaawa 'cotton' is functioning as an adjective modifying the head noun dua 'tree'. In this case both the modifier and the modified are both singular nouns. This means that a noun can modify a noun and if it precedes the head noun. Unlike (10h) where the modifier precedes the modified, in (10i-I) the modifiers come after the modified. For instance, in duagyeene and duamako; the modifiers gyeene "onion" and "mako" come after the modified 'dua' in both cases respectively.

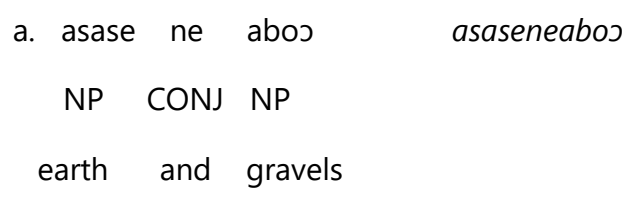




\section{palm oil and salt}

'Palm oil and salt'

Syntactically, noun-conjunction-nouns weed names in $(11 a, b)$ are considered a single unit. It is a noun phrase with both nouns functioning as heads. The weed names in this category are combined using conjunction ne 'and'. The ne 'and' is a noun phrase connective. These phrases are called conjoined Noun Phrases.
a. n-kwadaa n-kwadaa borsdec
Nkwadaankwadaaborodec
PLU-Child PLU-child plantain
'Childrens' plantain'
b. n-kwadaa n-kwadaa borsdee nini
Nkwadaankwadaaborodernini
PLU-child PLU-child plantain male
'Male childrens' plantain'

In (12a) the data revealed that the noun nkwadaankwadaa is functioning as an adjective modifying the head nouns borsdee 'plantain' respectively. This means that noun can modify nouns and when they do, it precedes the head noun. Similarly, in (12b), we observe that the gender nouns nini 'male' is a postmodifer. It modifies the noun nkwadaankwadaaborsdee.

\subsection{Sentential Weed Names}

The names with sentential structures were analyzed under two sub-categories: sentence function and sentence structure. The sentences by function were further categorized as declarative and imperative. See examples 12 and 13 respectively. There were no interrogative sentences in the Asante name system of the weeds. Structurally, the Asante weed names have been identified as simple, compound and complex sentences.

\subsection{Declarative Weed Names}

The analysis showed that Asante weed names can be declarative. They are statements written together as names. Declaratives are statements that express judgments, opinions or facts. Structurally, declaratives usually have their subjects coming before their verbs.

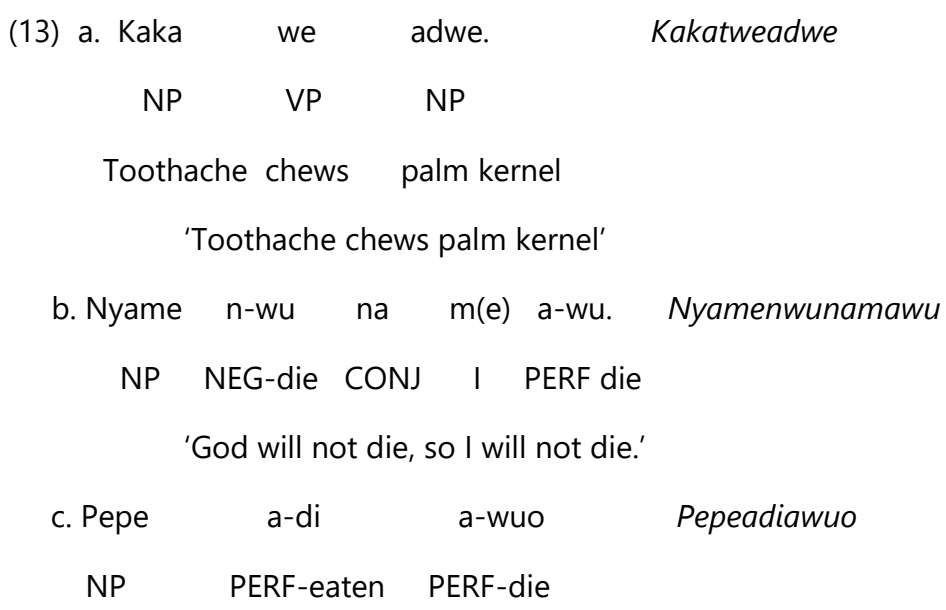

'A northerner ate and died.'

From the data in examples $(13 a-c)$, the Asante weed names have explicit subjects. In example (13a) the sentence has the structure SVO while $(13 b, c)$ have SV patterns. These statements are facts.

4.3.2 Imperative weed names

On the other hand, a command sentence usually has no subject and the verb is in the imperative mood. These kinds of clauses can have varying levels of intensity which is shown by fluctuating loudness and abruptness of voice quality (Dixon 2005: 30).
(14) a. Toa ntini
Toantini
VP NP 
Join veins

'Join wound.'

b. Twe ta Tweta

VP NP

Uproot fart

'Uproot and fart.'

c. $\mathrm{Gu}$ a-kuro Guakuro

V PLU-N

Collapse towns

'Deserted town.'

d. Kra wo ni Krawoni

VP 2SG-POSS NP

bid your mother

'Bid farewell to your mother.'

e. gyina Antwi Gyinantwi

VP NP

Stop Personal Name

'Stop Antwi'

f. Bo wo m-ma gu w(o) akyi Bowommaguwakyi

$\checkmark$ PRO PLU-N VP 2SG-poss PP

Bear your seeds at your back

g. Aberewa kata wo twe Aberewakatawotwe

NP VP 2SG-POSS NP

Old lady cover your vagina

'Old lady cover your vigina.'

As indicated in (14a-g) Asante weed names can be imperative clauses. The examples in (14a $-f$ ) have no palpable stated subjects. The covert subject in each case is the pronoun wo, 'you'. Thus, the subject wo is implied (Owu-ewie 2014). In (14g) however, the imperative clause has a subject Aberewa 'Old lady'.

4.3.3 Weeds Names with Simple Sentence Structures

A simple sentence contains a simple independence clause. It is the most basic type of sentence. It consists of only one main clause that can stand alone and does not depend on any other. According to (Afreh, 2006), a simple sentence can be as short as one word.

(15) a. Gyina Antwi Gyinantwi

VP $\quad P N$

Stop Personal name

'Stop Antwi!'

a-kuro

Guakuro

VP

PLU-NP

Collapse

towns

'Deserted town.' 

c. Kaka we adwe Kakaweadwe
NP $\quad$ VP NP
toothache chews palm kernel
'Tootache can chew palm kernel'
d. Aberewa kata wo twe Aberewakatawotwe
N V 2SG-POSS N
old lady cover your vagina
'Old lady cover your vigina.'

$\begin{array}{cccc}\text { e. Kra } & \text { wo } & \text { ni } & \text { Krawoni } \\ \text { VP } & \text { 2SG PRO } & \text { NP } & \\ \text { bid } & \text { your } & \text { mother } & \end{array}$

'Bid farewell to your mother'

$\begin{array}{llllll}\text { f. Bग wo m-ma } & \text { gu } & \text { w(o) } & \text { akyi } & \text { Bowommaguwakyi } \\ \text { VP PRO PLU-N } & \text { V } & \text { 2SG-POSS } & \text { PP } \\ \text { bear your seeds bear your } & \text { back }\end{array}$

'Bear your seeds behind you.'

The structure of the Asante weed names can be simple sentences with the constituents of a clause (subject, verb and object) as exemplified in (15a- $f$ ). It is observable from (15a-f) that the subjects of the simple clauses of weed names in Asante may have or may not be palpably stated. While the subjects in (15a, b, e, f) are covert, the constructions in (15c, $d$ ) have their subjects explicitly stated. The covert subject in each case is the pronoun, wo, 'you' which is implied as indicated by Owu-Ewie (2014). Structurally, the examples in (15a-e) have the clause pattern SVO consisting of subject, verb and noun (object) as shown in (15a-d). However, the constructions in (15e, f) have their subjects explicitly stated. In constructions, (15c, d), Kaka 'Toothache', and Aberewa 'Old lady' are head nouns and we 'chew', kata 'cover' function as verbs in the constructions while adwe 'palm kernel' and wo twe 'your vigina' are the objects. Since the object in each clause is one, the verbs are monotransitive. Wo twe 'your vigina' in (15d), wo ni 'your mother' (15e), w'akyi 'your back' and wo mma 'your seeds' in (15f) are possessive noun phrases.

4.3.4 Weeds with compound sentence structure

Structurally, the names of Asante weed names were compound sentences. According to (Afreh, 2006) compound sentence consists of two or more independent clauses joined by the co-ordinate conjunctions 'and', 'but' and 'or'. Like English, Asante, compound sentences are linked by co-ordinate conjunctions na 'and', anaa,'or' or nanso 'but'.
(16) a. Twe ta
Tweta

$\begin{array}{cl}\text { VP } & \text { VP } \\ \text { uproot } & \text { fart }\end{array}$
'Uproot and fart'
b. Nyame nwu na m(e) a-wu. Nyamenwunamawu.
NP NEG-die CONJ PRO PERF-die
'God wiil not die, so I will not die.'
c. Pepe
a-di
a-wu
Pepeadiawu
Northerner PERF-eat PERF-die

'A northerner ate and died.' 
It can be seen in (16a) that the construction Tweta does not have explicit coordinating conjunctions. This phenomenon is what Owu-Ewie (2014) referred to as 'asyndetic coordination'.. Twe (na) ta 'Uproot fart'. Here the two sentences are reduced to a single word to form a name for the plant. Meanwhile the example in (16b) has an overt subject. The two independent clauses are connected by explicit coordinating conjunction na 'and'. In (16c), there is a serial verb construction with the subject 'Pepe'. The two verbs in succession share the same subject 'Pepe'. The two verbs are inflected for tenses. The $\{a-\}$ in adi and awu are both perfect tense markers. This is typical for Akan serial verb constructions since they are normally inflected for the tense, indicated aspect, and polarity affixes. In (16a-c), it is realized that all the independent clauses in each compound sentence are intransitive in nature.

4.3.5 Weeds with Complex Sentence Structure

Complex constructions in Asante are composed of at least a subordinate clause and a main clause. The subordinate clause of Asante weed name in this category is characterised "by $(s \varepsilon)$..... $a$,. The $(s \varepsilon)$ components is optional but the $a$ (particle) and the comma are compulsory elements." (Owu-Ewie, 2014, p. 242).

$\begin{array}{rllll}\text { a. }(s \varepsilon \text { wo }) \text { tan } & \text { me } & \text { a, } & \text { wu } & \text { Tanmeawu } \\ \text { VP 1PRO } & \text { CON } & \text { VP } & \\ \text { hate me } & \text { if } & \text { die } & \end{array}$

'If you hate me, die.'

The data in (17a) demonstrated that, the construction is a complex sentence. The first part of the sentence which is a dependent clause ( $s \varepsilon$ wo)tan me $a$, 'If you hate me,' is a conditional clause. The construction has the imperative form wu 'die' as the second independent clause. It is a transitive construction and has a covert subject wo 'you'.

\section{Conclusion}

This study sought to discuss and analyze the morphosyntactic structures of Asante weed names. Katamba's (1993) Lexical Morphology theory developed from Generative Grammar was used for the study. In terms of distribution, the morphological components are engendered from morphemes by joining roots with other roots and with affixes at the syntactic level. These words are arranged to form phrases, clauses and sentences.

Morphologically, the study discovered that Asante weed names could be classified into mono-morphemic, di-morphemic and poly-morphemic. The mono-morphemic names have single word roots. Some are metaphoric in nature and do not express complete thought of the name-givers unless they are use in context. For example, kagya has covert meaning; however, when it is used in proverb with termite mount, it expresses symbiotic relationship. The data also revealed that the di-morphemic names formed as a result of compounding (noun-noun, verb-noun), reduplication and affixation. The poly-morphemic names are composed of phrases, conjoined clauses, reduplication-noun and sentences that function as indicative and imperative structures at the syntactic level. The phrasal and sentential names are made up of both free and bound morphemes. The bound morphemes are affixes.

The data demonstrated that syntactically, Asante weed names could be lexical phrasal, clausal and sentential structures. Functionally, there are declarative and imperative reduced to form weed names. Structurally, they were identified to be simple, compound and complex sentences. At the phrasal level, all the Asante weed names are noun phrases. The data above revealed that Asante weed names are endowed with rich linguistic properties ranging from phonology, morphology, syntax, and semantics. In a nutshell, Asante weed names like personal and other proper names have morphosyntactic rules influencing their formation among the Asantes (Akans). As illustrated in the study, these findings will add up to the limited literature on the language and the morphosyntactic study of plants names universally.

\section{Abbreviations Used}

$\mathrm{N}=$ Noun, $\mathrm{V}=$ verb, $\mathrm{PRO}=$ Pronoun, CONJ-Conjunction, NP =Noun Phrase, $\mathrm{PP}=$ Postposition, $\mathrm{PLU}=$ Plural Marker, PERF = Perfective, $\mathrm{POSS}=$ Possessive, $\mathrm{PROG}=$ Progressive, $\mathrm{SVO}=$ Subject, Verb, Object, V= Verb, VP= Verb Phrase, 2SG $=$ Second Person Singular Pronoun, 1PS=First Person Singular, 2SG. = Second Person Singular Pronoun

Conflict of interest: There was no conflict of interest declared by the author.

Funding: This research received no external funding."

Acknowledgments: Special thanks to my wife Deborah Karikari Anane and the participants for their unflinching support. 


\section{References}

[1] Adomako, K. (2017). Morphophonological Analysis of Akan Female Family-Name Formation. Ghana Journal of Linguistics, 6(3), 1-32.

[2] Afreh, E. S. (2006). Grammar and Usage for Tertiary Students. Kumasi: Kwame Nkrumah University of Science and Technology.

[3] Agyekum, K. (2006). The Sociolinguistic of Akan Personal Names. Nordic Journal of African Studies 15(2), $206-235$.

[4] Adrian, K. \& Noleen, S. T. (2019). Morphology of Zulu bird names: Old and new. South African Journal of African Languages, 39(1), 1-10.

[5] Anderson, J. M. (2007). The grammar of names. Oxford: Oxford University Press.

[6] Ansu-Kyeremeh, K. (2000). Communicating Nominatim: Some Social Aspects of Bono Personal Names. Research Review 16(2), $19-33$.

[7] Batoma, A. (2006). African Ethnonyms and Toponyms: An Annotated Bibliography. Electronic Journal of Africana Bibliography, 10(1), 1-40. doi.org/10.17077/1092-9576.1000

[8] Caesar, R. O. (2019). A Morphosyntactic Analysis of Dangme Allusive Names. Universal Journal of Language, 20(2), 53-93.

[9] Croft, W. (2001). Radical Construction Grammar Syntactic Theory in Typological Perspective. Oxford: Oxford University Press.

[10] De Klerk, V. (2002). Changing Names in the "New" South Africa: A Diachronic Survey. Names, 50(3), 201-221.

[11] Dolphyne, F. A. (2006). The Akan (Twi-English) Language: Its sound systems and tonal structure. Accra: Black Mask Printing Press

[12] Green, L. J. (2009). A Preliminary Linguistic Analysis of Plant Names in Ikpaná (Logba), an Endangered Ghana Togo Mountain Language. I ndependent Study Project (ISP) Collection. 751. https://digitalcollections.sit.edu/isp collection/751

[13] Haspelmath, M. (2010). Comparative concepts and descriptive categories in crosslinguistic studies. Language 86(3), 663-687

[14] Katamba, F. (1993). Morphology: Modern linguistics series. New Jersey: Prentice Hall Inc.

[15] Köhnlein, B. (2015). The morphological structure of complex place names: the case of Dutch. The Journal of Comparative Germanic Linguistics, 18(3), 183-212. doi.10.1007/s10828-015-9075-0

[16] Kongo, E. \& Eno, M. (2016). Language Learning: A Morphosyntactic Analysis of Contemporary Ewe Personal Names. (Proceedings of INCEDI 2016 Conference 3-17).Ghana: Methodist University College.

[17] Leyew, Z. (2011). Wild Plant Names and Traditional Botanical Knowledge among three Ethnolinguistic Communities of North-western Ethiopia. Organization for Social Science Research in Eastern and Southern Africa (OSSREA).

[18] Mwangi, K. P. (2015).What's in a Name? An Exposition of Gĩkũyũ Grammar through Personal Names. The International Journal of Humanities \& Social Sciences 5(9): 259-267.

[19] Mphande, L. (2006). Naming and Linguistic Africanism in African-American Culture. (Selected Proceedings of the 35th Annual Conference on African Linguistics 104-113). Somerville, MA: Cascadilla Press.

[20] Obeng, S. G. (1998). Akan-Death-Prevention-Names: A Pragmatic and Structural Analysis. Names 46(3), 63-187.

[21] Onukawa, M. C. (1995). A Re-Analysis of the So Called Igbo De-Sentential Nominal. In Wmenanjo N. \& Ndimele O. (eds.), Issues in African Languages and Linguistics: Essays in Honour of Kay Williamson 266-278.

[22] Owu-Ewie C. (2014). A Morphosyntactic Analysis of Some Fante Habitation Names (econym). The International Journal of Humanities \& Social Studies 2(5): 232-243.

[23] Pakia, M. (2006)._African Traditional Plant Knowledge Today: An Ethnobotanical Study of the Digo at the Kenya Coast. LIT Verlag Münster.

[24] Popay, I. (2008). Weeds of agriculture - Introduction of weeds. Te Ara-the Encyclopedia of New Zealand.

[25] Titov, E. (2019). Morphosyntactic encoding of information structure in Akan. Glossa: A Journal of General Linguistics, 4(1), 27.http://doiorg/10.5334/gigl.576

Van Langendonck, Willy and Mark Van de Velde. 2007. 'Naar een universele theorie van eigennamen [Towards a universal theory of proper names]', Handelingen van de Koninklijke Commissie voor Toponymie \& Dialectologie 74: 429-467.

[26] Van Langendonck, W., Van de Velde. M, \& Hough, C. (2016). Names and grammar. The Oxford Handbook of Names and Naming.

\section{Appendices}

Appendix 1: Asante weed names and their English Equivalence.

\section{S/N}

\section{1.}

2.

3.

4.

5.

6.

7.

8.

9.

10.
Weed name in Asante

Nyanya

Awobe

Nyanyamforowa

Nunum

Nsensan

Mfofo

Afama

Kagya

Apэsomp

Funtum

\section{English Gloss}

Covert

Covert

Covert

Covert

Covert

Covert

Covert

Covert

Covert

Covert

\section{Common/Botanical name}

Momordica charantia

Phyllanthus muellerianus

Mallotus oppositifolius

Ocimum gratissimum

Eleusinen indica

Melanthera scandens

Justicia flava

Griffonia simplicifolia

Pupalia lappacea

Funtumia elastic 
11.

12.

13.

14.

15.

16.

17.

18.

19.

20.

21.

22.

23.

24.

25.

26.

27.

28.

29.

30.

31.

32.

33.

34.

35.

36.

37.

38.

39.

40.
Ntropo

Akyeampon

Abirekyireabodwese

Adankoaduane

Akobowere

Anansedəkono

Ananseakekaduro

Akonfematiko

Adankomeleke

Akokommesa

Asaaawadua

Duagyeene

Duamako

Gyinantwi

Toantini

Adwera

Jnwono

Twenata

Ananseturomahoma

Nkascenkasee

Nkwadaankwadaaborodec

Kakatweadwe

Pepeadiawuo

Nyamenwunamawu

Aberewakatawotwe

Krawoni

Guakuro

Bowommaguwakyi

asaseneaboว

Ngonenkyene
Covert

Personal Name

Goat's weed

Rabbit's food

Parrot's claws

Spider's kenkey

Spider's ginger

Guinea fowl's comb

Rabbit's milk

Chicken's braided hair

Cotton's tree

Onion tree

Pepper tree

Stop Antwi

Join vein

Purification

Bitter

Uproot and fart

Thread in spider's anus

Thistles

Children's plantain

Toothache chews palm kennel

A northerner ate and died.

God will not die so I will not die.

Old lady cover your vagina.

Bid your mother goodbye.

Heal wounds

Bear your seed behind you.

Sand and gravels

Palm oil and salt
Tropical soda apple

Lamb's quarters

chromalaema odorata

Crowsfoot grass

Tridax procumbens

Lantana camara

Wild ginger

Heliotropium indicum/Heliotrope

Wild poinsettia

Scent weed/ African basil weed

Gossypium hirsutum

Nim tree Azadirachta indica

Drypetes aubrevillei

Bidens pilosa

Sweet gum

Paullinia pinnata

Mint

Vernonia amygdalina

Common wireweed (sida acuta)

Butterfly pea

(Centrosema pubescens)

Joyweed(Alternanthera pungens)

Cassia occidentalis

asthma weed

(Euphorbia hirta)

Solanum erianthum

Commelina

Mimosa pudica

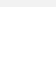

Cleistopholis patens 
41.

43.

44.

Tanmeawu

NkwadaankwadaaborJdernini

Nunumnini

borJfenini
If you hate me, die. Life plant (Bryophyllum pinnatumm)

\section{Male Cassia Senna occidentalis}

occidentalis

Male ocimum Hoslundia opposite gratissimum

Male papaya

Male papaya 